\title{
Strategies to Provide Scaffolding when Teaching Mathematical Reasoning
}

\author{
Mochamad Abdul Basir ${ }^{1}$, Dyana Wijayanti ${ }^{2}$ \\ Universitas Islam Sultan Agung, Indonesia ${ }^{1,2}$ \\ \{abdulbasir@unissula.ac.id¹,dyana.wijayanti@unissula.ac.id²\}
}

\begin{abstract}
This article aims to introduce the support of scaffolding strategies in improving mathematical reasoning skills. Mathematical reasoning is one of the abilities that students are expected to achieve in learning mathematics. If students' reasoning abilities are integrated into the curriculum, it will have a positive effect on learning mathematics in the classroom. However, not a few students are weak in reasoning abilities. In Surah an-Nisa verse 9 there is an invitation not to leave someone in a weak state. Therefore, the teacher's efforts in the form of scaffolding are needed by providing assistance in the form of assistance to students at the early stages of learning, then reducing this assistance and giving students the opportunity to take on greater responsibility after being able to do it themselves. Support for scaffolding strategies in improving students' mathematical reasoning abilities includes (1) Giving stimulus problems; (2) Explanation of problem formulation; and (3) Question and answer dialogue.
\end{abstract}

Keywords: Mathematical Reasoning, Scaffolding, Teaching Strategy

\section{Introduction}

Education is a learning process that is carried out systematically in order to develop the potential of students. The success of a learning process depends on a process of interaction, socialization and good communication between teachers and students. There are three realities faced by mathematics teachers. The first is the difference in students' math abilities over a wide range. The second reality, mathematical structures and concepts are coherent and connected - each skill builds towards other skills and concepts. These closely linked sequences of learning developments build on one another and require the acquisition of essential prerequisite skills. The third reality is that most teachers are required to use the same textbook or set of teaching materials for all students in a particular class.

In addition, learning success will be hampered if there are still students who have difficulty understanding the material. This difficulty can be caused by many factors, such as internal factors, which come from within the child and external factors, which come from outside of the child. Student difficulties allow errors in solving problems on certain material [1]. Error is a form of deviation from something that has been considered true or a form of deviation from things that were previously agreed or determined. The teacher must be able to recognize the problems faced by students, if ignored it can hinder students' intellectual development in 
achieving learning goals. The impact will appear a negative stigma on mathematics material which is considered difficult and of course affects student learning outcomes.

The difficulties experienced by students in understanding conceptual and procedural problems in solving mathematical problems do not mean the student cannot do it, but can be because students cannot know or understand the problems they get. Sometimes teachers do not realize that the problems faced by students are caused by the teacher's lack of role in the learning process. In addition, there is not a little bit of assistance provided by the teacher who has not paid attention to the location of difficulties faced by students [2]. Educators are effective if they are able to provide assistance to students with various approaches to learning that encourage active student involvement.

Mentioned in Q.S. AnNisa verse 9 has to do with the importance of education in Islam. The surah gives a signal that the form of neglecting a child is not giving him assistance in education, including the process of mentoring in gaining knowledge. In Surah An-Nisa verse 9 contains the meaning of the word about "Walyakhsya alladziina law tarakuu min khalfihim dzurriyyatan dhi'aafan khaafuu 'alayhim falyattaquu allaha walyaquuluu qawlan sadiidan”. Which means "And let those who fear their children leave behind them, whom they fear (their well-being). Therefore let them fear Allah and let them speak the truth". This surah contains the meaning that as an educator must be concerned about the well-being of learners who are weak in both knowledge and mental. Therefore, there is an effort for teachers to overcome the difficulties and mistakes made by students, one of them in learning mathematics.

Vygotsky argues that the Zone of Proximal Development (ZPD) is the distance between the actual level of development determined through independent problem solving and the potential level of development determined through problem solving under the guidance of adults or working with more capable friends.

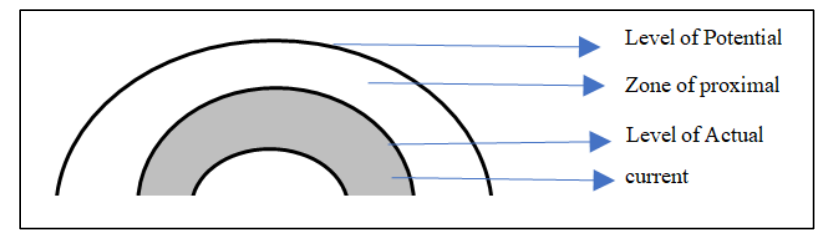

Fig. 1. Ilustration of ZPD Concept

The shaded areas represent the areas of development a learner acquires when learning alone without the help of others. Each individual's ZPD is always developing, but of course its development has limitations. ZPD is individual so that the provision of assistance in the classroom will vary depending on the level of ability of students.

The provision of various types and levels of assistance by educators to students in order to facilitate in order to solve the problems faced, by Vygotsky is called scaffolding. As explained by [3], that scaffolding is interpreted as the support provided by the teacher to students when doing a job / assignment where students may not be able to achieve. Scaffolding in mathematics learning as a didactic action in the form of measurable and limited assistance or encouragement for students provided by teachers who have more experience or knowledge in understanding mathematical concepts / procedures so that students can independently build knowledge and can solve math problems. The main purpose of scaffolding is to help students increase their involvement in learning and successfully complete tasks that are beyond their abilities [4]. 
Scaffolding needs to build on what students already know and be tied to continuous assessment of student abilities. Thus educators only tell students what to do or how to do it in order to qualify as a form of scaffolding. This is because in the previous learning approach there were no constructive activities from what the students already knew. Provision of scaffolding refers to assistance that is tailored to the learning needs of students [5]. Therefore, providing assistance (support) to students at the right time will create a better mathematics learning process. This is inseparable from active students and educators as facilitators. And improper assistance will cause interference. Usually interference appears as a form of expression of educators' concerns so that students succeed in learning. For this reason, the assistance given to students must always be "just enough" and "on time" so that students can do more and gradually become more responsible for their learning. At an advanced level, the form of assistance can be modified by students by changing, restructuring, or dismantling.

\section{Approach to the Scaffolding Review}

This study uses a literature review with a systematic approach to critically analyze the application of the scaffolding strategy in mathematics learning. According to Dixon-Woods, a systematic literature review is defined as a scientific process that is governed by a set of explicit and demanding rules oriented towards demonstrating completeness, immunity from bias, and transparency and accountability of techniques and execution [6]. This is a process of collecting qualitative and quantitative data from relevant literature to compare and evaluate the ability of a particular phenomenon to solve problems. The systematic review process is characterized by several criteria used to limit the scope of the review [7].

The studies used involved both quantitative and qualitative studies based on inclusion criteria developed at the start of the review process. The inclusion criteria are the standard for assessing the weight (evidence) in the study. included in the review, including topics (literature related to scaffolding strategies in mathematics learning), period (articles published in the last five years), research base (including both qualitative and quantitative empirical studies), transparency (explicitly mentioning sample size, instrument and analysis), and reliability / validity (the results of the study are valid and reliable according to the type of publication).

Literature is identified and filtered through six stages, (1) development of inclusion criteria, (2) search for related literatures in the Scopus indexed online journal database and national indexed gay journals by tracking titles, abstracts and keywords referring to scaffolding techniques in mathematics learning, (3) limiting findings to literature published in academic journals, conference proceedings, and e-books, (4) conducting a broader investigation of the literature to identify sample size, methodology and research results, (5) conducting literature analysis to construct an overview critical review of scaffolding strategies in mathematics learning, (6) drawing conclusions based on the final analysis that has been done and validated. 


\section{Result and Discussion}

\subsection{Review of Recent Scaffolding Literature in Mathematics Education}

Learning mathematics through mentoring with scaffolding is a concept based on Vygotsky regarding the zone of proximal development. Vygotsky states that students have actual levels of development and potential levels of development [8]. Stated that scaffolding assistance is based on students' actual abilities in order to achieve their potential abilities. With the application of scaffolding in mathematics learning, it can facilitate students in learning and can create effective learning [9]. Scaffolding is a way to restructure students' thinking into a correct thinking structure [10].

A task in the form of problem solving can be completed by students well if students can gradually find out the information needed to solve the problem, this can be achieved by the presence of scaffolding [11]. Scaffolding can work through a hierarchical program where students first solve low-level (simple) problems that can help students solve more difficult problems gradually until they reach complex problems [12]. The application of scaffolding can have an effect on the cognitive and emotional of students which not only has an impact on students 'skills and knowledge but can also increase students' motivation and confidence in completing tasks [13]. Scaffolding provides benefits to teachers and students who are involved in it. Scaffolding can improve students' creative thinking and divergent thinking skills, increase their freedom of opinion and participate in solving problems, and increase selfconfidence in mathematics learning.

Proposes three levels of the use of scaffolding which are support in mathematics learning, namely level 1 environmental provisions [2]. At this stage, the teacher's rule is to prepare a classroom learning environment such as group settings or student worksheets. in a group setting students will independently solve problems by exchanging ideas. Help can take the form of instructions or commands on a worksheet. Level 2 explaining, reviewing, and restructuring where explaining means that the teacher explains how to achieve an idea or concept that is used to solve mathematical problems. Reviewing means that the teacher checks again to encourage students to better understand and understand the problem to be solved. Meanwhile, restructuring means that the teacher rebuilds the knowledge that students already have to solve the problems. At level 3 developing conceptual thinking, the teacher directs students to improve conceptual thinking power. Teacher and student interaction in creating opportunities to express student understanding.

\subsection{Giving Stimulus Problems}

Before interacting with students, the teacher plans scaffolding learning by determining the learning environment including infrastructure and class organization which involves not only seating arrangements but also the sequence and arrangement of the learning process. With the right conditions, scaffolding learning can occur through interactions in the classroom such as teaching aids, audiovisual media or appropriate textbooks [14]. Structured assignments are given in the form of worksheets that are directed at managing student challenges in learning. In addition, modifying assignments to include elements of self-reflection can provide feedback that supports independent learning so that it not only finds solutions to mathematical problems, but also reflects on the processes involved in solving them. The form of scaffolding can also be through providing a scaffolding strategy in the form of modeling, bridging, or building a scheme. Modeling means a scaffolding strategy in the form of providing examples 
or models to solve mathematical problems. Stratgei bridges the scaffolding which is done by reviving students' knowledge and understanding of an existing concept. Whereas building a schema means assistance in the form of a schematic / diagram that describes the problem situation, perhaps the concept of a mind map related to the problem situation.

In general, learning activities with scaffolding can be carried out according to the amount of time allocated by the teacher to explain the material. The first scaffolding stage is the modeling stage where students listen to the verbal explanation from the teacher and follow what is exemplified. At this stage the teacher is still intensively providing guidance to students in completing assignments given by the teacher [15]. Support assistance at the beginning of learning is provided by the teacher to students in a structured and systematic manner so that students are independent in learning. Further sated that the scaffolding technique facilitates activities and tasks that motivate students; simplify assignments to make them easier for students to complete or accomplish; provide direction in helping students to focus on achieving goals; reduce frustration; and provide clear direction on the ultimate goal of the activities undertaken [16]. Description and scaffolding techniques performed [12] in the early stages include Elicting, the teacher provides assistance in the form of questions or questions that generate responses from students; Inferential Questioning, the teacher helps students to use evidence in making conclusions; Predicting, helps students make predictions; Drawing Attention to relevant features of a problem or of the environment, helps students use "sense" to narrow the field of observation to the focus of investigation or current discourse; Give hints, teachers provide instructions to help with ongoing student investigations.

Based on research [10], in the early stages of scaffolding the teacher prepared student worksheets containing procedures for constructing graphs of functions and practice questions and preparing geogebra to help students' visualization skills. Also argued that teachers need to diagnose students' learning difficulties as a reference in making improvements to plan further learning. In an effort to improve algebraic reasoning, the first form of scaffolding is the teacher directs students to pay attention and provides feedback in finding solutions and reflecting on the processes in these solutions [17].

\subsection{Explanation of Problem Formulation}

At this stage it involves direct interaction between teachers and students related specifically to the mathematics material being studied. besides identifying patterns of interaction that are more responsive to students which then develop focus on ideas. Through this strategy, the teacher maintains control and devises strategies to take into account the next steps that are not in line with students' thinking. This is because it can add to student difficulties. When the teacher gives problems to discuss, students can reconcile ideas. [18] argues that scaffolding aids can include illustrations, hints, motivations, warnings, key words, an outline of the problem to simpler steps towards how to solve the problem, giving examples, and other assistance which should all be clear and relevant to make it possible. students to achieve a developmental level of independent learning.

Provide scaffolding in the form of explaining strategies in solving problems in order to obtain the correct solution [11]. Roehler and Cantlon [13] Characteristics of scaffolding as follows Offering explanations, the explanation is in the form of a firm statement that is tailored to the students' understanding of what will be studied and also why, when, and how it is used; inviting students participation, Students are given the opportunity to participate in the learning process. After the educator provides an illustration of understanding the material then completed with the assignment, students have the opportunity to complete it according to what 
they know and understand. Described the scaffolding technique through Provide Materials, the teacher provides a tool to support ongoing activities or investigations; validation Feedback, a statement that communicates "yes, thats right!"; Correction Feedback, when students make statements that are factually inaccurate or use the term in an inaccurate manner, the teacher offers information to clarify the truth which is actually inaccurate; Denomination, the teacher gives exact terms for unclear or wrong concepts; Expansion, the teacher adds to the statements made to students; Generalization, the teacher mentions higher concepts associated with specific examples identified by students; Exemplary, the teacher provides specific examples of general concepts that are named or referred to by students [12].

Based on research [10] at this stage students were asked to read back the problems given by the teacher, then write down what was known and asked about the questions. Furthermore, students are asked to draw a graphic sketch of the problem given, as well as explain the steps taken. [17] The teacher describes the subject matter and then assigns students to explore their own understanding of the material that has been obtained by providing a mathematical statement. The scaffolding strategy carried out [20], through guidance in determining what strategies students should do in observing and manipulating objects, discussing various mathematical concepts contained in observed objects or games in learning outside the classroom, inviting students to provide conclusions that are procedural in nature.

\subsection{Asking and Question Dialogue}

Mathematics learning involves more than the ability to imitate taught procedures and solve isolated problems. In mathematics there are special needs because teachers seek concept development through processes of generalization and abstraction. So that there is a teaching interaction that explicitly discusses the development of conceptual thinking by creating opportunities to express understanding to students and teachers simultaneously. When students are supported in making connections and developing representational ranges, permanently transferable skills and understandings can be communicated [11]. Provide scaffolding in the form of directive questions so that students understand the meaning of the variables. In addition, it also provides directional questions by identifying the characteristics of the material and asking students to reread the problem and discuss other alternative solutions in solving the problem.

The characteristics of scaffolding are as follows: verifying clarifying students understandings, if the understanding that appears is as expected, educators can test the responses of students. Conversely, if it is not as expected, educators can clarify the truth; modeling of desired behaviors, a teaching attitude that shows how a person should feel, think, or act in accordance with a given situation including demonstrations of thinking hard, speaking aloud and demonstrations of performance, and inviting students to contribute clues. Students are encouraged to provide related ideas. with what to complete in the assignment [13].

Based on research [10] at the final stage of scaffolding, teachers and students conduct questions and answers to explore the difficulties experienced by students and lead to the correct answer. Description of scaffolding technique according to [12] Link to Previous Knowledge and / or Experience, the teacher refers to what he or she knows is the child's previous experience or knowledge to answer new questions; Co-participating, the teacher counts together with the child, starts a sequence or fills in numbers; Contextualization, draws new knowledge closer by creating a new intermediate level of representation to connect the concepts introduced with others that students build direct experience; De-Contextualization, 
moving the concept away from the current context [19]. The form of scaffolding that can be given by providing instructions or orders to correct it in the final answer; Provide questions and commands so that students think again with the information provided in the questions so that they can write the explanations correctly; Provide questions or commands for reflection on the answers that have been written; Provide information on the procedure for solving other problems of the same type; Rebuild the initial understanding so that you can plan to solve the problems correctly; Provide instructions or orders to re-examine the work.

The teacher directs students to see, touch, say what he thinks; directing students to explain and interpret what students do and say through inducement questions [17]. The teacher and students conclude the overall results of the discussion of the learning process through question and answer dialogue [20].

\section{Conclusion}

The form of scaffolding strategy given by the teacher is in the form of assistance to students in the early stages of learning, then reduces assistance and provides opportunities for students to take on greater responsibility after being able to do it themselves. Support for scaffolding strategies in improving students' mathematical reasoning abilities includes (1) giving stimulus problems, (2) Explanation of problem formulation and (3) a question and answer dialogue.

\section{References}

[1] Fatahillah, A., Yuli fajar Wati N.T., \& Susanto. 2017. Analisis Kesalahan Siswa dalam Menyelesaikan Soal Cerita Matematika Berdasarkan Tahapan Newman Beserta Bentuk Scaffolding yang Diberikan. Kadikma 8(1): 40-51.

[2] Anghileri, J. 2006. Scaffolding Practices that Enhance Mathematics Learning. Journal of Mathematics Teacher Education. 9(1). 33-52

[3] Van de Pol, J., Volman, M. \& Beishuizen, J. 2010. Scaffolding in Teacher-Student Interaction: A Decade of Research. Educ Psychol Rev (22). 271-296.

[4] Kusmaryono. 2020. The Role of Scaffolding in the deconstructingof thinking structure: a case study of pseudo-thinking process. Infinity Journal, 9(2), 247-262.

[5] Bakker, A, Jantien Smith., \& Rupert Wgerif. 2015. Scaffolding and dialogic teaching in mathematics education: introduction and review. ZDM Mathematics Education 47: $1047-1065$

[6] Khalaf, B.K., \& Zin, Z.B.M. 2018. Traditional and Inquiry-based learniing pedagogy: A siystematic critical review. International Journal of Intruction, 11(4), 545-564.

[7] Martins, L.E.G., \& Gorschek, T. 2016. Requirements engineering for safety-critical systems: A systematic literature review. Information and Software Technology, 75, 7189.

[8] Damayanti, S., Danugiri, D., Sopiany, H.N., 2018. Sinergitas Teknik Scaffolding dengan Model Problem Based Learning terhadap Kemampuan Matematis. Prosiding Seminar Nasional Matematika dan Pendidikan Matematika. Universitas Singaperbangsa Karawang: 196-200

[9] Anwar, Yuwono, Irawan Edy B \& As'ari A.R. 2017. Investigation of Contingency Patterns of Teachers scaffolding in teaching and learning mathematics. Journal on Matheatics Education, 8(1), 65-76. 
[10] Tyaningsih, R.Y., Novitasari, D., Hamdani, D., Handayani, A.D., \& Samijo, S. (2020). Pemberian Scaffolding terhadap berpikir pseudo penalaran siswa dalam mengkonstruksi grafik fungsi. Journal of Science and Education (JSE). 1(1) : 20-31

[11] Setiawan, R. \& Mitasari, Z. 2020. Penerapan Scaffolding sebagai Upaya dalam Meningkatkan Level Berpikir Matematis Siswa Ditinjau dari taksonomi SOLO. MUST: Journal of Mathematics Education, Science, and Technology, 5(1): 68-79

[12] Zurek, Torquati, \& Acar, 2014. Scaffolding as atool for Environment Education in Early Chilhood. International Journal of Early Chillhood Environment Education, 29(1):27-57

[13] Bikmaz, F.H., Celebi O., Ata A., Ozer E., Soyak O., \& Recber H. 2010. Scaffolding Strategies Apllied by Student Teachers to Teach Mathematics. The International Journal of Research in Teacher Education 1 (Special Issue): 25-36

[14] Basir, M.A., \& Aminudin, M. 2020. Pengembangan Buku Teks Matematika Berbasis Investigasi untuk Meningkatkan Penalaran Aljabar. Journal of Medives: Journal of Mathematics Education IKIP Veteran Semarang, 4(1), 53-62

[15] Subiyakto, A., Rufiana I.S., \& Nurhidayah D.A. 2020. Peningkatan Kemampuan Komunikasi Matematis Siswa Menggunakan Pembelajaran Kooperatif Tipe Two Stay Two Stray Berbantuan Teknik Scaffolding. Jurnal Edukasi Matematika dan Sains (JEMS), 8(1): 7-17

[16] Stuyf, V. D. 2002. Scaffolding as a teaching stratgey. Adolescent Learning and Development. Section 0500A-Fall 2002

[17] Rahayu, P. Warli, W., \& Cintamulya, I. 2020. Scaffolding dalam Pembelajaran mata Kuiah Struktur Aljabar. Jurnal Ilmiah Pendidikan Matematika, 5(1).

[18] Belland, B.R. 2017. Instructional Scaffolding in STEM Education. Springer Cham Heidelberg New York Dordrecht London.

[19] Rahayuningsih, P \& Abdul Qohar. 2014. Error Analysis in Solving Word Problem About Two Variabel Linear Equations and its Scaffolding Based on Newman Error Analysis on Studnets Grade VII of Malang State Junior High School. Jurnal Pendidikan Matematika dan Sains. 2(2). 119-116

[20] Yunita. 2020. Pengaruh Pembelajaran Luar Kelas dengan Teknik Scaffolding terhadap Kemampuan Komunikasi Matematis Siswa. Jurnal Pendidikan Matematika Rafkesia (JPMR) 5(1), 112-126 